\title{
PENGARUH SKEPTISME PROFESIONAL DAN PENGALAMAN AUDITOR TERHADAP KEMAMPUAN AUDITOR EKSTERNAL DALAM MENDETEKSI KECURANGAN (SURVEI PADA AUDITOR BPK RI PERWAKILAN SULAWESI UTARA)
}

\author{
Monica Mokoagouw ${ }^{1}$, Lintje Kalangi ${ }^{2}$, Natalia Gerungai ${ }^{3}$ \\ ${ }^{1,2,3}$ Fakultas Ekonomi dan Bisnis, Jurusan Akuntansi, Universitas Sam Ratulangi, Jl.Kampus Bahu, Manado, \\ 95115, Indonesia
}

E-mail : Monicamokoagouw@gmail.com

\begin{abstract}
External auditor is an independent and competent person who can examine financial statements and be responsible for the opinions given. This research aims to examine the effect of professional skepticism and auditor's experience on fraud detection ability of external auditor. The sample in this research are all auditors who work in Badan Pemeriksa Keuangan (BPK) Republik Indonesia (The Indonesia's Supreme Audit Institution) Reprensentative of North Sulawesi Province. The data of this research is using primary data. The data was collected by distributing questionnaires directly to auditors of BPK RI Representative of North Sulawesi Province. This research is using the multiple linear regression analsys with SPSS 23. The result indicate that: 1) Professional Skepticism has positive effect towards Fraud Detection Ability of External Auditor. 2) Auditor's Experience has positive effect towards Fraud Detection Ability of External Auditor. 3) Professional Skepticism and Auditor's Experience simultaneously have positive effect towards Fraud Detection Ability of External Auditor.
\end{abstract}

Keywords: Professional Skepticism, Auditor's experience, Fraud Detection Ability of External Auditor.

\section{PENDAHULUAN}

Seiring dengan tuntutan publik atas transparansi dan akuntabilitas pengelolaan keuangan pemerintah, maka kebutuhan akan laporan pertanggungjawaban pengelolaan keuangan pemerintah yang tidak memihak (independen) dan menyajikan fakta apa adanya makin meningkat. Informasi akuntansi berupa laporan keuangan menjadi sesuatu yang mutlak. Untuk menilai keandalan laporan keuangan yang dibuat oleh pemerintah, diperlukan pengawasan secara independen terhadap kinerja pertanggungjawaban atas penggunaan dana. Untuk pengawasan secara independen terhadap kinerja pertanggungjawaban pemerintah maka diperlukan auditor eksternal. Berdasarkan UU No.17 Tahun 2003 tentang keuangan negara dan UU No. 1 Tahun 2004 tentang perbendaharaan negara, mengamanatkan pemeriksaan yang independen kepada Badan Pemeriksa Keuangan Republik Indonesia (BPK RI).

Pengelolaan keuangan disektor pemerintah maupun swasta tidak lepas dari risiko terjadinya kecurangan. Dalam Standar Pemeriksa Keuangan Negara (SPKN) No 01 Tahun 2017 menyatakan bahwa seorang auditor harus mengindentifikasi faktor risiko kecurangan dan menilai risiko adanya ketidakpatuhan terhadap ketentuan peraturan perundang-undangan yang disebabkan oleh kecurangan (fraud) dan/atau ketidakpatuhan. Kecurangan yang marak terjadi dalam lingkungan pemerintahan seperti korupsi, manipulasi lapiran keuangan dan penyalagunaan aset. Kasus korupsi yang terjadi di Indonesia mengakibatkan kerugian negara yang tidak sedikit. Antara lain kasus korupsi pengelolaan dana pensiun PT Pertamina yang mencapai Rp 599,29 miliar. Nilai kerugian keuangan negara ini dihitung dari audit 
investigasi. BPK menyimpulkan adanya penyimpangan untuk kegiatan investasi saham khusus pada pembelian saham PT Sugih Energy Tbk. BPK dalam auditnya menemukan penyimpangan dalam proses perencanaan, pelaksanaan maupun pembayaran untuk kegiatan investasi saham PT Sugih Energy (www.news.detik.com). Di Indonesia terdapat kasus yang melibatkan kegagalan auditor independen dalam mendeteksi kecurangan. Menurut anggota V BPK Moermahadi Soerja Djanegara auditor yang mengaudit laporan keuangan Kementerian Dalam Negeri pada tahun 2012 memperlihatkan kurangnya sikap skeptisme. Dalam pemeriksaan ini BPK menemukan penyajian persediaan blangko $e$-KTP pada Kementerian Dalam Negeri yang tidak seluruhnya didukung oleh hasil rekonsiliasi antar dokumen secara memadai, serta pencatatan dan pelaporan aset tetap yang berasal dari tugas pembantuan yang tidak tertib (www.akuntanonline.com). Di Sulawesi Utara terdapat beberapa kasus korupsi yang melibatkan auditor Badan Pemeriksa Keuangan (BPK) RI Perwakilan Provinsi Sulawesi Utara. Salah satunya pada tahun 2016 bekas auditor BPK RI Provinsi Sulawesi Utara, Bahar, dijatuhi hukuman 5 tahun 6 bulan penjara, karena terbukti pernah meloloskan Laporan Hasil Pemeriksaan sejumlah pemerintah kabupaten dan pemerintah kota di Sulawesi Utara. Syaratnya, pemkab atau pemkot yang bersangkutan harus menyetor uang sebesar Rp1,6 miliar kepadanya (www.puslit.dpr.go.id).

Tindak kecurangan terus terjadi dengan berbagai cara yang terus berkembang, menuntut auditor untuk meningkatkan kemampuan auditor dalam mendeteksi kecurangan. Kemampuan setiap auditor dalam mendeteksi kecurangan berbeda-beda. Hal ini dipengaruhi oleh faktor internal maupun faktor eksternal. Namun faktor yang lebih dominan mempengaruhi adalah faktor internal, yang merupakan faktor yang berasal dari dalam diri auditor, seperti skeptisme profesional dan pengalaman auditor.

Sikap skeptisme profesional berarti auditor membuat penilaian kritis dengan pikiran yang selalu mempertanyakan kecukupan dan ketepatan bukti yang diperoleh selama pemeriksaan (SPKN No. 1 Tahun 2017). Auditor yang memiliki sikap skeptisme professional yang tinggi akan membuat auditor tersebut untuk selalu mencari informasi yang lebih banyak dan lebih signifikan daripada auditor yang memiliki tingkat skeptisme professional yang rendah, dan hal ini mengakibatkan auditor yang memiliki tingkat skeptisme profesional yang tinggi akan lebih dapat mendeteksi adanya fraud karena informasi tambahan yang mereka miliki tersebut (Fullerton dan Durtschi, 2004). Seorang auditor harus mempunyai pengalaman dalam kegiatan auditnya, pendidikan formal, dan pengalaman kerja dalam profesinya. Semakin bertambahnya pengalaman dapat dilihat dari pelatihan teknis yang dilakukan oleh auditor tersebut, lamanya dia bekerja, seberapa banyak klien yang telah diauditnya, dan berapa lama masa dia bekerja sebagai auditor itu sendiri (Mulyadi, 2013). Seorang auditor yang berpengalaman akan lebih mudah mengetahui indikasi adanya kecurangan dan dapat memberikan solusi yang tepat pula dalam menangani kecurangan (Wardhani, dikutip dalam Ranu \& Merawati, 2017).

Tingkat tanggungjawab auditor dalam mendeteksi kecurangan adalah sama walaupun terdapat perbedaan tingkat skeptisme profesional yang dimiliki auditor dan banyaknya pengalaman auditor. Auditor BPK sebagai auditor yang melakukan pemeriksaan terhadap pengelolaan keuangan negara dituntut untuk dapat memberikan keyakinan yang memadai kepada publik mengenai pengelolaan keuangan negara.

\section{TINJAUAN PUSTAKA}

\subsection{Kecurangan (Fraud)}

Kecurangan (fraud) adalah perbuatan yang mengandung unsur kesengajaan, niat, menguntungkan diri sendiri atau orang lain, penipuan, penyembunyian atau penggelapan, dan penyalahgunaan kepercayaan yang bertujuan untuk memperoleh keuntungan secara tidak sah yang dapat berupa uang, barang/harta, jasa, dan tidak membayar jasa, yang dilakukan oleh 
satu individu atau lebih dari pihak yang bertanggung jawab atas tata kelola, pegawai, atau pihak ketiga (SKPN No 1 Tahun 2017). Menurut Theodorus Tuanakotta (2013:351) kemampuan auditor dalam pendeteksian kecurangan berkaitan dengan teknik-teknik yang dikuasai auditor sebagai bekal dalam menjalankan tugasnya. Teknik yang dimaksud dapat berupa teknik dalam mengaudit laporan keuangan, kemampuan audit investigatif untuk kejahatan terorganisir dan penyelundupan pajak penghasilan, kemampuan audit investigatif dalam pengungkapan kecurangan pengadaan barang dan jasa.

\subsection{Skeptisme Profesional Auditor}

Arens, Elder, dan Beasley (2013) yang dialih bahasakan oleh Amir Abadi Jusuf mendefinisikan skeptisisme professional sebagai suatu sikap auditor yang tidak mengasumsikan manajemen tidak jujur tetapi juga tidak mengasumsikan kejujuran absolut. Menurut SPKN No. 1 Tahun 2017 skeptisme profesional berarti pemeriksa tidak menganggap bahwa pihak yang bertanggung jawab adalah tidak jujur, tetapi juga tidak menganggap bahwa kejujuran pihak yang bertanggung jawab tidak dipertanyakan lagi. Menurut Hurt et al., 2010 dalam Alwee dan Iskandar (2013) karakteristik skeptisme profesional dibentuk oleh beberapa faktor, seperti:

1. Questioning Mind

2. Suspension of Judgement

3. Search for Knowledge

4. Interpersonal Understanding

5. Self Confidence

6. Self Determination

\subsection{Pengalaman Auditor}

Menurut Agoes (2012) pengalaman auditor adalah auditor yang mempunyai pemahaman yang lebih baik. Mereka juga lebih mampu memberikan penjelasan yang masuk akal atas kesalahan-kesalahan dalam laporan keuangan dan dapat mengelompokkan kesalahan berdasarkan pada tujuan audit dan struktur dari sistem akuntansi yang mendasar. Pengalaman audit oleh Mulyadi (2013) merupakan akumulasi gabungan dari semua yang diperoleh dari interaksi.

\subsection{Pengaruh Skeptisme Profesional Auditor terhadap Kemampuan Auditor Eksternal dalam Mendeteksi Kecurangan.}

Menurut SPKN No. 1 Tahun 2017 dalam pelaksanaan pemeriksaan dan penyusunan laporannya, auditor wajib menggunakan kemahiran profesionalnya secara cermat dan saksama dengan memperhatikan prinsip-prinsip pelayanan atas kepentingan publik serta memelihara integritas, obyektivitas, dan independensi dalam menerapkan kemahiran profesionalnya terhadap setiap aspek pekerjaannya. Seorang auditor perlu mempertahankan pikiran yang selalu mempertanyakan selama audit berlangsung untuk mengidentifikasi risiko kecurangan dan mengevaluasi bukti audit secara kritis (Arens et al., 2012). Sehingga dengan menggunakan skeptisme profesionalnya, maka seorang auditor dapat mendeteksi terjadinya salah saji baik yang disebabkan oleh kekeliruan maupun yang disebabkan oleh kecurangan.

Penelitian yang dilakukan oleh Connell dan Banks (2003), menujukkan bahwa skeptisme profesional auditor berpengaruh terhadap kemampuan auditor dalam mendeteksi kecurangan. Maka dalam melakukan proses pengauditan auditor harus mampu mempertahankan sikap skeptisme profesionalnya sehingga memudahkan auditor dalam menemukan adanya kecurangan dalam laporan keuangan yang diperiksa.

Berdasarkan uraian tersebut maka dirumuskan hipotesis pertama :

$\mathrm{H}_{1}$ : Skeptisme profesional auditor berpengaruh positif terhadap kemampuan auditor eksternal dalam mendeteksi kecurangan. 


\subsection{Pengaruh Pengalaman Auditor terhadap Kemampuan Auditor Eksternal dalam Mendeteksi Kecurangan.}

Dalam SPKN No. 1 Tahun 2017 menyatakan bahwa tim pemeriksa harus secara kolektif memiliki pengetahuan, pengalaman, dan kompetensi yang diperlukan dalam pemeriksaan. Hal ini termasuk pengetahuan dan pengalaman praktis dari pemeriksaan yang dilakukan, pemahaman atas standar dan ketentuan peraturan perundang-undangan, pemahaman tentang operasional entitas, serta kemampuan dan pengalaman untuk mempraktikkan pertimbangan profesional. Penelitian yang dilakukan oleh Arsendy (2017) menunjukkan bahwa auditor yang memiliki pengalaman audit tinggi cenderung memiliki kemampuan mendeteksi kecurangan yang tinggi pula dan sebaliknya jika seorang auditor yang memiliki pengalaman audit yang rendah akan cenderung kurang baik dalam mendeteksi kecurangan.

Berdasarkan uraian tersebut maka dirumuskan hipotesis kedua :

$\mathrm{H}_{2}$ : Pengalaman auditor berpengaruh positif terhadap kemampuan auditor eksternal dalam mendeteksi kecurangan

\subsection{Pengaruh Skeptisme Profesional dan Pengalaman Auditor terhadap Kemampuan Auditor Eksternal dalam Mendeteksi Kecurangan.}

Menurut SPKN No. 1 Tahun 2017 seorang pemeriksa harus melakukan pemeriksaan dengan sikap profesionalisme. Sikap profesional pemeriksa diwujudkan dengan selalu bersikap skeptisisme profesional (professional skepticism) selama proses pemeriksaan dan mengedepankan prinsip pertimbangan profesional (professional judgment). Bertambahnya pengalaman dapat meningkatkan ketelitian dalam melakukan pemeriksaan dan sekaligus mengasah sikap skeptisme profesional yang dimiliki oleh setiap auditor. Dengan demikian sikap skeptisme profesional dan pengalaman auditor dapat mendukung peningkatan kemampuan auditor dalam mendeteksi kecurangan. Penelitian Rahmadhany (2015) menunjukkan bahwa skeptisme profesional dan pengalaman auditor berpengaruh positif dan signifikan terhadap pendeteksian kecurangan. Dengan demikian penelitian Rahmadhany membuktikan bahwa semakin meningkat skeptisme seorang auditor maka akan semakin baik pula kemampuan mendeteksi kecurangan serta semakin berpengalaman seorang auditor, maka akan semakin tinggi atau semakin baik dalam mendeteksi kecurangan.

Berdasarkan uraian tersebut maka dirumuskan hipotesis ketiga :

$\mathrm{H}_{3}$ : Skeptisme profesional dan pengalaman auditor secara simultan berpengaruh terhadap kemampuan auditor eksternal dalam mendeteksi kecurangan.

\section{METODE PENELITIAN}

\subsection{Jenis dan Sumber Data}

Jenis penelitian yang digunakan adalah penelitian kuantitatif. Berdasarkan hubungan antar variabel, maka penelitian ini merupakan penelitian korelasional, yaitu untuk menentukan apakah terdapat hubungan antara variabel independen yaitu skeptisme profesional auditor $\left(\mathrm{X}_{1}\right)$ dan pengalaman auditor $\left(\mathrm{X}_{2}\right)$ terhadap variabel dependen yaitu kemampuan auditor eksternal dalam mendeteksi kecurangan (Y). Sumber data yang digunakan dalam penelitian ini adalah data primer yang secara langsung bersumber dari responden tanpa ada perantara, dalam hal ini adalah jawaban atas pertanyaan dan pernyataan yang ada dalam kuesioner.

\subsection{Sampel dan Teknik Pengambilan Sampel}

Populasi dalam penelitian ini adalah auditor BPK RI Perwakilan Provinsi Sulawesi Utara. Teknik pengambilan sampel yang digunakan adalah nonprobability sampling, dengan menggunakan purposive sampling, yaitu teknik pengambilan sampel berdasarkan kriteria yang telah ditentukan (Kuncoro:2014). Berdasarkan teknik pengambilan sampel tersebut, maka kriteria yang digunakan dalam penelitian ini adalah sebagai berikut: 
1. Responden memiliki pengalaman kerja sebagai auditor minimal 1 tahun.

2. Jumlah penugasan yang dilakukan selama 1 tahun minimal 5 penugasan.

3. Responden tidak dibatasi oleh jabatan auditor.

Sampel dalam penelitian ini berjumlah 40 auditor BPK RI Perwakilan Provinsi Sulawesi Utara.

\subsection{Metode Analisis}

Metode analisis data yang digunakan dalam penelitian ini adalah analisis regresi linier berganda (Multiple Regression Analysis) dengan bantuan program Statistical Product and Service Solution (SPSS) versi 23. Analisis ini dimaksudkan untuk mengetahui pengaruh beberapa variabel bebas terhadap variabel variabel terikat. Analisis regresi linear berganda diawali dengan uji kualitas data, uji ini untuk mengetahui ketepatan alat ukur dalam mengukur objek yang diteliti. Model analisis regresi memerlukan uji asumsi klasik, untuk menginterpretasikan data agar lebih relevan dalam menganalisis. Uji asumsi klasik yang digunakan adalah uji normalitas, uji multikolinearitas, dan uji heteroskedastisitas.

\section{HASIL ANALISIS DAN PEMBAHASAN}

\subsection{Hasil Analisis}

\subsubsection{Uji Kualitas Data}

\section{A. Uji Validitas}

Sebuah kuesioner yang digunakan dalam penelitian harus valid. Arti valid disini yaitu mampu menunjukkan arah sampai sejauh mana alat ukur mampu mengukur apa yang ingin diukur. Jika korelasi antara skor masing-masing pertanyaan dengan skor total mempunyai tingkat signifikan $<0,05$, maka pertanyaan tersebut dinyatakan valid dan sebaliknya (Ghozali, 2011).

Tabel 4.1 Hasil Uji Validitas Skeptisme Profesional Auditor $\left(\mathbf{X}_{1}\right)$

\begin{tabular}{cccc}
\hline $\begin{array}{c}\text { Nomor } \\
\text { Pertanyaan }\end{array}$ & $\begin{array}{c}\text { Pearson } \\
\text { Correlation }\end{array}$ & Signifikansi & $\mathbf{5 \%}$ \\
\hline 1 & 0,443 & 0,004 & 0,05 \\
2 & 0,539 & 0,000 & 0,05 \\
3 & 0,513 & 0,001 & 0,05 \\
4 & 0,707 & 0,000 & 0,05 \\
5 & 0,460 & 0,003 & 0,05 \\
6 & 0,687 & 0,000 & 0,05 \\
7 & 0,535 & 0,000 & 0,05 \\
8 & 0,325 & 0,041 & 0,05 \\
9 & 0,432 & 0,005 & 0,05 \\
10 & 0,415 & 0,008 & 0,05 \\
\hline
\end{tabular}

Sumber : Data olahan SPSS(2018) 
Tabel 4.2 Hasil Uji Validitas Pengalaman Auditor $\left(\mathrm{X}_{2}\right)$

Nomor

Pearson

Signifikansi $\quad \mathbf{5 \%}$

Pertanyaan

\section{Correlation}

\begin{tabular}{llll}
\hline 1 & 0,503 & 0,001 & 0,05 \\
2 & 0,476 & 0,002 & 0,05 \\
3 & 0,418 & 0,007 & 0,05 \\
4 & 0,633 & 0,000 & 0,05 \\
5 & 0,628 & 0,000 & 0,05 \\
6 & 0,504 & 0,001 & 0,05 \\
7 & 0,438 & 0,005 & 0,05 \\
8 & 0,430 & 0,006 & 0,05 \\
9 & 0,379 & 0,016 & 0,05 \\
10 & 0,503 & 0,001 & 0,05
\end{tabular}

Sumber : Data olahan SPSS(2018)

Tabel 4.3 Hasil Uji Validitas Kemampuan Auditor Eksternal dalam Mendeteksi

Kecurangan (Y)

\begin{tabular}{cccc}
\hline $\begin{array}{c}\text { Nomor } \\
\text { Pertanyaan }\end{array}$ & $\begin{array}{c}\text { Pearson } \\
\text { Correlation }\end{array}$ & Signifikansi & $\mathbf{5 \%}$ \\
\hline 1 & 0,475 & 0,002 & 0,05 \\
2 & 0,525 & 0,001 & 0,05 \\
3 & 0,576 & 0,000 & 0,05 \\
4 & 0,669 & 0,000 & 0,05 \\
5 & 0,422 & 0,007 & 0,05 \\
6 & 0,575 & 0,000 & 0,05 \\
7 & 0,407 & 0,009 & 0,05 \\
8 & 0,483 & 0,002 & 0,05 \\
9 & 0,736 & 0,000 & 0,05 \\
10 & 0,550 & 0,000 & 0,05 \\
\hline
\end{tabular}

Sumber : Data olahan SPSS(2018)

Uji validitas menunjukkan bahwa semua pertanyaan untuk masing-masing variabel memiliki kriteria valid dengan nilai signifikansi $<0,05$ sehingga semua pertanyaan tersebut dapat digunakan untuk mengukur masing-masing variabel.

\section{B. Uji Reliabilitas}

Uji reliabilitas dimaksudkan untuk menguji konsistensi kuesioner dalam mengukur suatu konstruk yang sama atau stabilitas kuesioner jika digunakan dari waktu ke waktu 
(Ghozali, 2011). Uji reliabilitas dilakukan dengan cara menghitung koefisien cronbach alpha $>0,60$ maka dapat disimpulkan bahwa instrumen penelitian tersebut reliabel.

Tabel 4.4 Hasil Uji Reliabilitas

\begin{tabular}{|c|c|c|}
\hline Variabel & Cronbach's Alpha & Keterangan \\
\hline Skeptisme Profesional Auditor & 0,670 & Reliabel \\
\hline Pengalaman Auditor & 0,645 & Reliabel \\
\hline $\begin{array}{l}\text { Kemampuan Auditor Eksternal } \\
\text { dalam Mendeteksi Kecurangan }\end{array}$ & 0,735 & Reliabel \\
\hline
\end{tabular}

Sumber : Data olahan SPSS(2018)

Tabel 4.4 menunjukkan semua pertanyaan untuk setiap variabel setiap variabel memiliki nilai koefisien cronbach's alpha $>0,60$, maka dapat disimpulkan bahwa seluruh pertanyaan dalam kuesioner reliabel.

\subsubsection{Uji Asumsi Klasik}

\section{A. Uji Normalitas}

Uji normalitas dalam penelitian ini menggunakan rumus Kolmogorov-Smirnov. Dasar pengambilan keputusan untuk uji normalitas yaitu jika nilai signifikansi lebih besar dari 0,05 maka data tersebut berdistribusi normal dan sebaliknya.

Tabel 4.5 Hasil Uji Normalitas

One-Sample Kolmogorov-Smirnov Test

\begin{tabular}{|cc|r|}
\hline & & \multicolumn{1}{|c|}{ Unstandardized Residual } \\
\hline \multicolumn{2}{|c|}{$\mathrm{N}$} & 40 \\
Normal Parameters ${ }^{\mathrm{a}, \mathrm{b}}$ & Mean &, 0000000 \\
& Std. Deviation & 1,69475625 \\
Most Extreme Differences & Absolute &, 101 \\
& Positive &, 101 \\
& Negative &,- 066 \\
& &, 101 \\
Test Statistic & &, $200^{\mathrm{c}, \mathrm{d}}$ \\
\hline
\end{tabular}

Sumber : Data olahan SPSS(2018)

Tabel 4.5 menunjukkan nilai signifikansi $>0,05$. Hal ini dibuktikan dengan nilai asymp. Sig 0,200 >0,05, menunjukkan bahwa data telah berdistribusi secara normal.

\section{B. Uji Multikolinearitas}

Uji multikolinearitas dilakukan untuk mendeteksi gejala korelasi antara variabel independen yang satu dengan variabel independen yang lain. Dengan melihat nilai tolerance dan nilai Variance Inflation Factors (VIF). Jika nilai tolerance $>0,10$ dan VIF $<10$ maka dinyatakan tidak ada korelasi sempurna antara variabel independen (Ghozali, 2011).

\section{Tabel 4.6 Hasil Uji Multikolinearitas}

Coefficients $^{\mathrm{a}}$

\begin{tabular}{|c|c|c|c|}
\hline \multirow{2}{*}{\multicolumn{2}{|c|}{ Model }} & \multicolumn{2}{|c|}{ Collinearity Statistics } \\
\hline & & Tolerance & VIF \\
\hline \multirow[t]{3}{*}{1} & (Constant) & & \\
\hline & Skeptisme Profesional Auditor & ,996 & 1,004 \\
\hline & Pengalaman Auditor & ,996 & 1,004 \\
\hline
\end{tabular}

Sumber : Data olahan SPSS(2018) 
Tabel 4.6 menunjukan nilai tolerance setiap variabel independen $>0,10$ dan nilai VIF setiap variabel independen $<10$, sehingga penelitian ini tidak mengalami multikolinearitas, sehingga salah satu syarat uji regresi berganda telah terpenuhi.

\section{Uji Heteroskedastisitas}

Uji heteroskedastisitas dalam penelitian ini menggunakan uji Glesjer. Apabila koefisien signifikansi lebih besar dari tingkat signifikansi yang ditetapkan, maka dapat disimpulkan tidak terjadi heteroskedastisitas (Thoifah, 2015: 222).

Tabel 4.7 Hasil Uji Heteroskedastisitas dengan Uji Glesjer

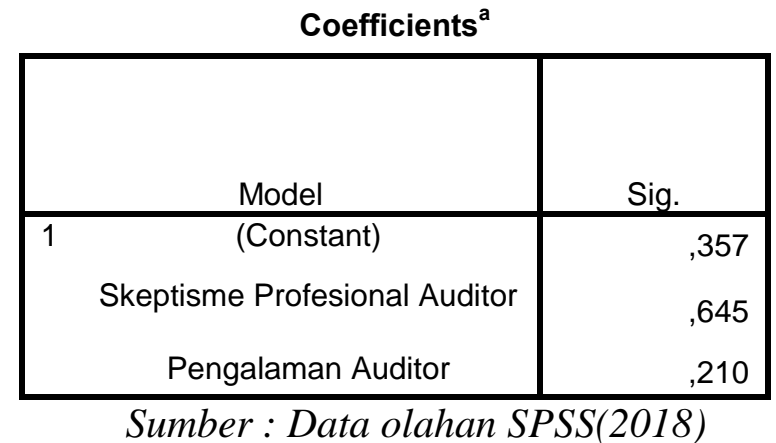

Tabel 4.7 menunjukkan signifikansi variabel skeptisme profesional sebesar 0,645 dan variabel pengalaman auditor sebesar 0,210, menunjukkan signifikansi $>0,05$. Maka dapat disimpulkan bahwa tidak terjadi heteroskedastisitas pada model regresi.

\subsubsection{Analisis Regresi Linear Berganda}

Tabel 4.8 Hasil Analisis Regresi

Coefficients $^{\mathrm{a}}$

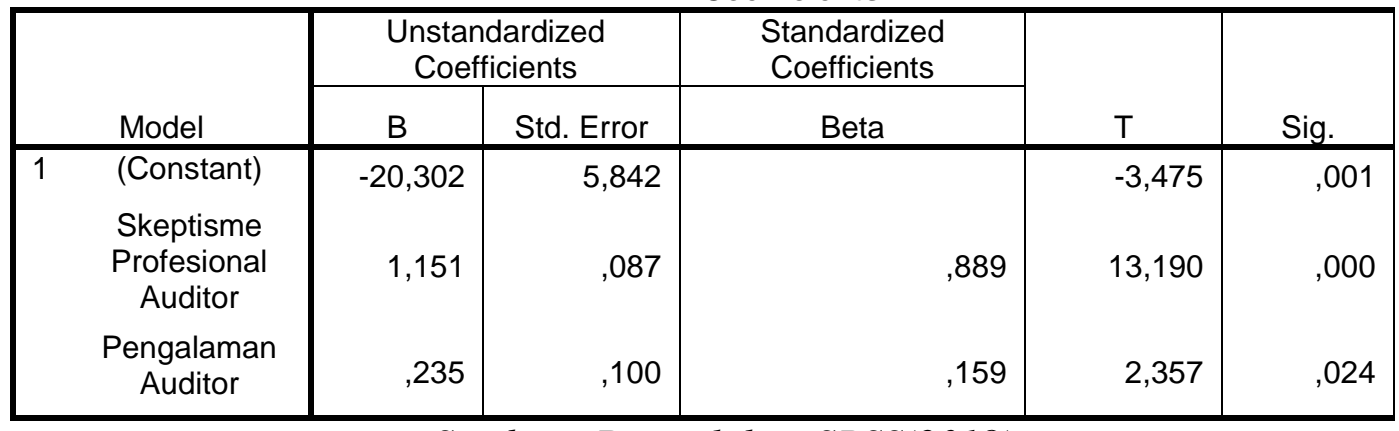

Sumber : Data olahan SPSS(2018)

Berdasarkan tabel 4.8 diperoleh persamaan regresi berganda sebagai berikut :

$$
Y=-20,302+1,151 X_{1}+0,235 X_{2}+\varepsilon
$$

Dengan interpretasi bahwa :

1. Nilai konstanta $(\alpha)$ sebesar $-20,302$ bernilai negatif artinya jika variabel skeptisme profesional dan pengalaman auditor dianggap sama dengan 0, maka skor kemampuan auditor eksternal dalam mendeteksi kecurangan akan semakin berkurang.

2. Variabel skeptisme profesional $\left(\mathrm{X}_{1}\right)$ memiliki nilai koefisien regresi $\left(\beta_{1}\right)$ sebesar 1,151 dan bernilai positif, menunjukkan bahwa skeptisme profesional auditor memiliki pengaruh positif terhadap kemampuan auditor eksternal dalam mendeteksi kecurangan.

3. Variabel pengalaman auditor $\left(X_{2}\right)$ memiliki nilai koefisien regresi $\left(\beta_{2}\right)$ sebesar 0,235 dan bernilai positif, menunjukkan bahwa pengalaman auditor memiliki pengaruh positif terhadap kemampuan auditor eksternal dalam mendeteksi kecurangan. 


\section{A. Uji Simultan (Uji F)}

Pada penelitian ini, uji $\mathrm{F}$ digunakan untuk mengetahui apakah secara simultan koefisien variabel independen mempunyai pengaruh nyata atau tidak terhadap variabel dependen.

\section{Tabel 4.9 Hasil Uji Simultan (Uji F)}

ANOVA $^{\mathrm{a}}$

\begin{tabular}{|c|c|c|c|c|c|c|}
\hline & Model & Sum of Squares & Df & $\begin{array}{c}\text { Mean } \\
\text { Square }\end{array}$ & $\mathrm{F}$ & Sig. \\
\hline \multirow[t]{3}{*}{$\overline{1}$} & Regression & 556,959 & 2 & 278,480 & 91,985 &, $000^{b}$ \\
\hline & Residual & 112,016 & 37 & 3,027 & & \\
\hline & Total & 668,975 & 39 & & & \\
\hline
\end{tabular}

Sumber : Data olahan SPSS(2018)

Tingkat signifikansi dalam penelitian ini adalah 0,05 . Penentuan $\mathrm{F}_{\text {tabel }}$ menggunakan ketentuan $\mathrm{df}=\mathrm{n}-\mathrm{k}-1(\mathrm{df}=40-2-1=37)$, sehingga didapat nilai $\mathrm{F}_{\text {tabel }}$ sebesar 3,25.

Tabel 4.9 menunjukkan hasil analisis menggunakan $\mathrm{F}_{\text {hitung }}=91,985>\mathrm{F}_{\text {tabel }}=3,25$ dengan signifikansi $0,000<0,05$, maka dapat disimpulkan variabel skeptisme profesional auditor dan pengalaman auditor secara simultan berpengaruh signifikan terhadap kemampuan auditor eksternal dalam mendeteksi kecurangan.

\section{B. Uji Parsial (uji t)}

Pada penelitian ini, uji t digunakan untuk menguji apakah hipotesis yang diajukan dalam penelitian ini diterima atau tidak dengan mengetahui apakah variabel independen secara individual mempengaruhi variabel dependen.

\section{Tabel 4.10 Hasil Uji Parsial (uji t)}

Coefficients $^{\mathrm{a}}$

\begin{tabular}{|c|c|c|c|c|c|}
\hline \multirow[b]{2}{*}{ Model } & \multicolumn{2}{|c|}{$\begin{array}{l}\text { Unstandardized } \\
\text { Coefficients }\end{array}$} & \multirow{2}{*}{$\begin{array}{c}\begin{array}{c}\text { Standardized } \\
\text { Coefficients }\end{array} \\
\text { Beta }\end{array}$} & \multirow[b]{2}{*}{$\mathrm{T}$} & \multirow[b]{2}{*}{ Sig. } \\
\hline & $\mathrm{B}$ & Std. Error & & & \\
\hline (Constant) & $-20,302$ & 5,842 & & $-3,475$ & ,001 \\
\hline Skeptisme Profesional Auditor & 1,151 & ,087 & ,889 & 13,190 & ,000 \\
\hline Pengalaman Auditor & ,235 &, 100 & ,159 & 2,357 & 024 \\
\hline
\end{tabular}

Sumber : Data olahan SPSS(2018)

Metode dalam penentuan $\mathrm{t}_{\text {tabel }}$ menggunakan $\mathrm{df}=\mathrm{n}-\mathrm{k}-1(\mathrm{df}=40-2-1=37)$, sehingga didapat nilai $t_{\text {tabel }}$ sebesar 1,687.

Berdasarkan tabel 4.10, variabel skeptisme profesional auditor menunjukkan nilai $t_{\text {hitung }}$ sebesar 13,190 $>\mathrm{t}_{\text {tabel }}$ sebesar 1,687 dengan signifikansi sebesar 0,000 $<0,05$. Hal ini menunjukkan bahwa secara parsial skeptisme profesional auditor memiliki pengaruh signifikan terhadap kemampuan auditor eksternal dalam mendeteksi kecurangan. Jadi, hipotesis $\mathrm{Ha}_{1}$ diterima dan $\mathrm{Ho}_{1}$ ditolak.

Variabel pengalaman auditor menunjukkan nilai $t_{\text {hitung }}$ sebesar 2,357 $>t_{\text {tabel }}$ sebesar 1,687 dengan signifikansi sebesar $0,024<0,05$. Hal ini menunjukkan bahwa secara parsial pengalaman auditor memiliki pengaruh signifikan terhadap kemampuan auditor eksternal dalam mendeteksi kecurangan. Jadi, hipotesis $\mathrm{Ha}_{2}$ diterima dan $\mathrm{Ho}_{2}$ ditolak.

\section{Koefisien Determinasi}

Menurut Ghozali (2013: 197), koefisien determinasi $\left(\mathrm{R}^{2}\right)$ pada intinya mengukur seberapa jauh kemampuan model dalam menerangkan variasi variabel dependen. 


\section{Tabel 4.11 Hasil Koefisien Determinasi Model Summary ${ }^{\mathrm{b}}$

\begin{tabular}{|r|r|r|}
\hline \multicolumn{1}{|c|}{ Model } & \multicolumn{2}{|c|}{ R Square } \\
\hline 1 &, $912^{\mathrm{a}}$ &, 833 \\
\hline
\end{tabular} \\ Sumber : Data olahan SPSS(2018)}

Berdasarkan tabel 4.11 besarnya R Square adalah 0,833, nilai ini menunjukkan, 83,3\% variasi kemampuan auditor BPK RI Perwakilan Provinsi Sulawesi Utara dalam mendeteksi kecurangan dapat dijelaskan oleh variabel skeptisme profesional auditor $\left(\mathrm{X}_{1}\right)$ dan pengalaman auditor $\left(\mathrm{X}_{2}\right)$, sisanya $16,7 \%$ dijelaskan oleh variabel lain yang tidak diteliti dalam penelitian ini.

\subsection{Pembahasan}

Hasil pengujian hipotesis pertama menunjukkan, semakin tinggi skeptisme profesional yang dimiliki auditor, maka semakin tinggi pula kemampuan auditor BPK RI Perwakilan Provinsi Sulawesi Utara dalam mendeteksi kecurangan.

Hasil pengujian hipotesis kedua menunjukkan, semakin bertambahnya pengalaman auditor dalam melakukan audit maka membuat auditor BPK RI Perwakilan Provinsi Sulawesi Utara semakin cepat dalam mendeteksi kecurangan.

Hasil pengujian hipotesis ketiga menunjukkan, semakin tinggi skeptisme profesional auditor dan semakin bertambahnya pengalaman auditor maka akan meningkatkan kemampuan auditor BPK RI Perwakilan Provinsi Sulawesi Utara eksternal dalam mendeteksi kecurangan.

\section{KESIMPULAN DAN SARAN}

\subsection{Kesimpulan}

Berdasarkan hasil penelitian dan pembahasan pada bab sebelumnya, maka disimpulkan bahwa:

1. Skeptisme profesional auditor $\left(\mathrm{X}_{1}\right)$ berpengaruh secara signifikan terhadap kemampuan auditor eksternal dalam mendeteksi kecurangan $(\mathrm{Y})$, sehingga hipotesis pertama diterima. Hal ini menunjukkan bahwa semakin tinggi skeptisme profesional yang dimiliki auditor, maka semakin tinggi pula kemampuan auditor eksternal dalam mendeteksi kecurangan, sehingga kemungkinan terjadinya kecurangan juga semakin kecil.

2. Pengalaman auditor $\left(\mathrm{X}_{2}\right)$ berpengaruh secara signifikan terhadap kemampuan auditor eksternal dalam mendeteksi kecurangan (Y), sehingga hipotesis kedua diterima. Hal ini menunjukkan bahwa semakin bertambahnya pengalaman auditor dalam melakukan audit maka membuat auditor semakin cepat dalam mendeteksi kecurangan.

3. Skeptisme profesional dan pengalaman auditor secara simultan berpengaruh secara signifikan terhadap kemampuan auditor eksternal dalam mendeteksi kecurangan, sehingga hipotesis ketiga diterima. Dari hasil penelitian ini memenunjukkan bahwa semakin tinggi skeptisme profesional dan semakin bertambahnya pengalaman auditor maka akan meningkatkan kemampuan auditor eksternal dalam mendeteksi kecurangan.

\subsection{Saran}

Berdasarkan hasil penelitian dan kesimpulan, maka peneliti memberikan saran:

1. Bagi BPK RI Perwakilan Provinsi Sulawesi Utara, untuk meningkatkan sikap skeptisme profesional auditor yang berdasarkan karakteristik skeptisme profesional yaitu questioning mind, suspension of judgement, search for knowledge, interpersonal understanding, dan self determination, terutama dalam setiap melaksanakan penugasan 
audit dengan mengikuti diklat (pendidikan dan pelatihan) berkelanjutan serta mengadakan forum diskusi antar sesama auditor secara lebih intensif, sehingga dapat meningkatkan perilaku berpikir secara kritis dan berpikir alternatif. Selain itu, perlu adanya peningkatan sistem pengawasan internal BPK, untuk mampu memastikan bahwa seluruh proses di BPK sudah dilaksanakan sesuai dengan ketentuan dan prosedur yang ada. BPK harus melakukan evaluasi internal, khususnya dalam menegakkan akuntabilitas sesuai dengan prinsip independensi, integritas, dan profesional, salah satunya dengan merotasi auditor dan lembaga yang diaudit, termasuk merotasi wilayah pengawasan kementerian.

2. Bagi penelitian berikutnya, supaya dalam pembagian kuesioner tidak dilakukan pada saat pemeriksaan dan peneliti selanjutnya diharapkan dapat memperluas ruang lingkup penelitian, tidak hanya BPK RI Perwakilan Provinsi Sulawesi Utara sehingga hasil penelitian dapat digeneralisasi untuk lingkup yang lebih luas. Peneliti berikutnya juga diharapkan dapat menambah variabel bebas (kompetensi, independensi, tekanan waktu, dan komunikasi interpersonal) yang belum bisa digambarkan dalam penelitian ini.

\section{DAFTAR PUSTAKA}

Agoes, Sukrisno. 2012. Auditing Petunjuk Praktis Pemeriksaan Akuntan Oleh Akuntan Publik. Buku 1. Salemba Empat. Jakarta.

Alwee, Sayed, \& Takiah Iskandar. 2013. Exploratory Factor Analysis on Hurtt's Professional Skepticism Scale: A Malaysian Perspective. Asian Journal of Accounting and Governance 4: 11-19.

Arsendy, Muhammad. 2017. Pengaruh Pengalaman Audit, Skeptisme Profesional, Red Flags dan Tekanan Anggran Waktu terhadap Kemampuan Auditor dalam Mendeteksi Kecurangan (Studi Empiris pada Kantor Akuntan Publik di DKI Jakarta). Jurnal Fakultas Ekonomi Vol. 4 No. 1. Universitas Riau.

Arens, Alvin A., Randal J. Elder \& Mark S. Beasley. 2012. Auditing and Assurance Services: an Intelegent Approach. di alih bahasakan oleh Herman Wibowo. Salemba Empat. Jakarta.

Arens, Alvin A., Randal J. Elder \& Mark S. Beasley. 2013. Auditing and Assurance Service : An Integrated Approach di alih bahasakan oleh Amir Abadi Jusuf. Salemba Empat. Jakarta.

Badan Pemeriksa Keuangan RI. 2017. Standar Pemeriksaan Keuangan Negara No. 01 Tahun 2017. Peraturan Badan Pemeriksa Keuangan Republik Indonesia. Jakarta

Connell Mc, Donald K. \& George Y. Banks.2003. Expanded guidance for auditor fraud detection responsibilities. The CPA Journal 73(6), pp: 28-33.

Djanegara, Moermahadi Soerja. 2012. Audit BPK terhadap KEMENDAGRI Harus Ditindaklanjuti. www.akuntanonline.com diakses tanggal 11 Desember 2017.

Fullerton, Rosemary R. \& Cindy Durtschi. 2004. The Effect of Professional Skepticism on The Fraud Detection Skills of Internal Auditors. Working Paper. Utah State University. http://www.ssrn.com/abstract=1140267 diakses tanggal 11 Desember 2017.

Ghozali, Imam. 2013. Aplikasi Analisis Multivariat dengan Program IBM SPSS 21. Edisi Ketujuh. Universitas Dipenogoro. Semarang.

Hikmawati, Putri. 2017. Dugaan Suap dalam Mendapatkan Opini WTP. Vol. IX, No. 11/I/Puslit/Juni/2017 www.puslit.dpr.go.id diakses tanggal 20 April 2018.

Kuncoro, Mudrajad. 2014. Metode Riset untuk Bisnis \& Ekonomi. Edisi Keempat. Erlangga. Jakarta.

Medistiara, Yulida. 2017. Kerugian Negara Kasus Dana Pensiun Rp. 599 Miliar. www.news.detik.com diakses tanggal 11 Desember 2017. 
Mulyadi. 2013. Sistem Akuntansi edisi 3. Salemba Empat. Jakarta.

Rahmadhany, Febrina. 2015. Pengalaman, Independensi, Skeptisme Profesional, Kompetensi dan Komunikasi Interpersonal Auditor KAP terhadap Pendeteksian Kecurangan (Studi Empiris Pada KAP Di Wilayah Pekanbaru, Medan, dan Batam). Jurnal Fakultas Ekonomi Vol. 2 No. 2. Universitas Pekanbaru.

Ranu, Gusti \& Luh Merawati. 2017. Kemampuan Mendeteksi Fraud Berdasarkan Skeptisme Profesional, Beban Kerja, Pengalaman Audit dan Tipe Kepribadian Auditor. Jurnal Riset Akuntansi Vol.7 No.1. Universitas Mahasaraswati Denpasar.

Republik Indonesia, 2003. Undang-Undang Nomor 17 Tahun 2003 tentang Keuangan Negara.

Republik Indonesia, 2004. Undang-Undang Nomor 1 Tahun 2004 tentang Perbendaharaan Negara.

Thoifah, I'anatut. 2015. Statistika Pendidikan dan Metode Penelitian Kuantitatif. Madani. Malang.

Tuanakotta, Theodorus,. 2013. Audit Berbasis ISA (International Standards on Auditing). Salemba Empat. Jakarta. 